\title{
Beverage Influence on Direct Restorations
}

\author{
${ }^{1}$ Ali AR Al-Shekhli, ${ }^{2}$ Isra'a AA Aubi
}

\section{ABSTRACT}

Aim: The aim of this study was to evaluate and compare the beverages effect on the microhardness of composite and compomer direct restorative materials in comparison with mineral water.

Materials and methods: Two types of direct restorative materials of A3 shade were selected for this study: Composan Bio-esthetic Nano-ceram Composite (PROMEDICA) and Composan compomer (PROMEDICA). Forty specimens were prepared from each restorative material (total number of specimens were 80 ). Each specimen was prepared by compressing a sufficient amount of material into a mold of $4 \mathrm{~mm}$ in diameter and $2 \mathrm{~mm}$ in thickness by two glass slides with acetate celluloid strip in between and curing the specimen for 20 seconds from only the top surface by making the curing tip in intimate contact with the acetate celluloid strips covering the composite and compomer surface with LED Woodpacker light curing unit. The top and bottom surfaces were divided into two halves: 1st half was subjected to microhardness testing before immersion, while microhardness testing was performed on the 2 nd half after immersion in beverages. $\mathrm{PH}$ values were recorded for each beverage solution with $\mathrm{pH}$ meter (Mettler Toledo, Canada). Vickers microhardness testing was performed with a microhardness tester (Microhardness tester FM-800, Future-Tech, Japan) at $300 \mathrm{~g}$ load and 15 seconds according to ISO 4049 for both top and bottom surfaces by making three indentations and considering the mean microhardness value for each surface to be the Vickers hardness number for that surface. Three types of beverages were used in the study (Coca Cola, orange juice, Red Bull) and a fourth immersion solution of mineral water was used as a control group. The 80 specimens were immersed for 30 days at $37^{\circ} \mathrm{C}$. The immersion solutions were replaced in a daily manner. After immersion, the composite and compomer specimens were incubated in distilled water at $37^{\circ} \mathrm{C}$ for 24 hours before the microhardness testing.

Data were statistically analyzed before and after immersion of the 80 specimens using mean, standard deviation, one way ANOVA and t-test at a $5 \%$ level of significance.

Results: One-way analysis of variance (ANOVA) for VHN composite top, bottom, and compomer top, bottom revealed that there was a statistically significant difference $(p \leq 0.05)$. t-tests comparing all the groups before and after immersion showed that there were statistically significant differences $(p \leq 0.05)$ in all groups being tested in this study. $\mathrm{pH}$ values for all the solutions were recorded as the followings: $\mathrm{pH}$ for Cola was 1.87, orange juice was 2.63, Red Bull was 2.55 and for water was 6.96 .

1,2Department of Restorative, College of Dentistry, Ajman University, Fujairah, United Arab Emirates

Corresponding Author: Ali AR AI-Shekhli, Department of Restorative, College of Dentistry, Ajman University, Fujairah, United Arab Emirates, Phone: 00971503905595, e-mails: alirazooki@yahoo.com
Conclusion: (a) All the beverages being tested including mineral water groups significantly resulted in general microhardness reduction; (b) Compomers tops and bottoms displayed a significantly general lower hardness values than composite restorative materials before and after immersion; (c) Composites showed higher differences in microhardness values than compomers in all the beverages when microhardness values were being compared before and after immersion; (d) Water sorption was the major factor affecting the microhardness rather than the acidic component of the different beverages used in the study; (e) Orange juice was significantly the highest beverage in microhardness reduction of both restorative materials.

Clinical significance: Beverages contain chemical components and their acidic nature or water content might affect the hardness of direct restorative materials that might lead to the degradation at the matrix/filler interface by acid attack and consequently a negative effect on the general performance of the affected restoration in oral service.

Keywords: Beverages, Compomer, Composite, Microhardness and soft drinks.

How to cite this article: Al-Shekhli AAR, Aubi IAA. Beverage Influence on Direct Restorations. World J Dent 2019;10(1): 52-57.

\section{Source of support: Nil}

Conflict of interest: None

\section{INTRODUCTION}

Composite and compomer are direct restorative materials, they are one of the effective tooth-colored materials. ${ }^{1}$ Composite resins are used in dentistry, and they are a type of synthetic resin insoluble, esthetic, insensitive to dehydration, easy to manipulate and reasonably inexpensive. ${ }^{2}$ Compomers are used in dentistry and they were introduced as a hybrid of two other dental materials, dental composites, and glass ionomer cement. Important compomer properties are: fluoride release, ease of use and aesthetics. ${ }^{3}$ Maintaining the restoration integrity, is an important consideration in their clinical service as there are several factors can affect the longevity and hardness of the restorations: patient motivation, oral hygiene, dentist's skill, techniques have been used for the placement of restorative materials, types of materials being used, habits and beverages consumption. Beverages and their acidity might affect the wear of composite and compomer, due to their potential in the resulted destruction at the matrix $\backslash$ filler interface by acid attack. ${ }^{4}$ Hamouda ${ }^{5}$ found that, low $\mathrm{pH}$ beverages adversely affected the properties of the tested restorative materials in their study and concluded that microhardness of tested materials was 
significantly decreased after immersion in the various beverages, as surface roughness and solubility were increased. Among the properties related to the hardness of material are strength, proportional limit, and ductility. Furthermore, hardness is indicative of the ease of finishing of a structure and its resistance to in-service scratching. ${ }^{6}$ Clinical performance of dental restorations could be affected by $\mathrm{pH}$ changes in the oral cavity. Consumption of acidic food, fruit juices, soft drinks, coffee, tea, or wine can result in surface damage and decrease hardness and esthetic qualities of restorative material. ${ }^{7}$ The increased consumption of sports and energy drinks among the general population has raised questions about their erosive potential on the dental hard tissues, as well as their effects on the clinical performance of restorative materials. ${ }^{8}$ Because of the increased consumption of low pH beverages, the materials' surfaces may become rough and dull at a clinically detectable level. ${ }^{5}$ The aim of this study was, to evaluate and compare the effect of low $\mathrm{pH}$ beverages on microhardness of composite and compomer direct restorative materials at their top and bottom surfaces in comparison with mineral water.

\section{MATERIALS AND METHODS}

Four types of immersion solutions available in the UAE market were used in this study: (Coca-Cola, orange juice, Red Bull and water as a control group). The composition of each beverage and mineral water used in this study are shown in Table 1.

Two types of direct restorative materials of A3 shade were selected for this study: Composan Bio-esthetic Nano-ceram Composite (PROMEDICA) and Composancompomer (PROMEDICA). Forty specimens were prepared from each restorative material (total number of specimens were 80 ). Each specimen was prepared by using a metal mold ( $2 \mathrm{~mm}$ in thickness and $4 \mathrm{~mm}$ in diameter), by placing the restorative material in the mold compressing the materials using two glass slide with two celluloid strips in between, and curing the specimens from only the top surface for 20 seconds with LED Woodpacker light curing unit. The top and bottom surfaces were divided into two halves: 1st one was subjected to microhardness testing before immersion, while the 2nd half was subjected to microhardness testing after immersion. $\mathrm{pH}$ values were recorded for each solution with $\mathrm{pH}$ meter (Mettler Toledo, Canada) to determine its acidity level. Vickers microhardness testing was performed with Vickers microhardness tester (Microhardness tester FM-800, FUTURE-TECH, Japan) (Fig. 1) at $300 \mathrm{~g}$ load and 15 seconds according to ISO 4049 by making three indentations of both top and bottom surfaces and considering the mean value to be recorded as Vickers hardness number of that surface. The eighty specimens (40 composites +40 compomer) were assigned into eight groups (G1-G8) $(n=10)$ as being described in Table 2 according to the type of restorative material and immersion solution. Three types of beverages were selected (Coca-Cola, orange juice, Red bull) plus a fourth immersion solution of mineral water was used as a control group. The 80 specimens were immersed for 30 days at $37^{\circ} \mathrm{C}$. The immersion solutions were replaced in a daily manner. After immersion, the composite and compomer specimens were incubated in distilled water at $37^{\circ} \mathrm{C}$ for 24 hours before the microhardness testing.

Data was statistically analyzed before and after immersion of the 80 specimens using mean, standard deviation, one way ANOVA and t-test at a 5\% level of significance.

\section{RESULTS}

Mean VHN and standard deviation at the top, the bottom of G1-G8 being tested before and after immersion

Table 1: The composition of each beverage immersion solution used in this study (manufacturer's data)

\begin{tabular}{|c|c|c|c|}
\hline Cola (Coca Cola) & Orange juice (Rani) & Red Bull & Water (Arwa) \\
\hline $\begin{array}{l}\text { Phosphoric acid, } \\
\text { water, caramel } \\
\text { colours, coca-flavors, } \\
\text { carbohydrates } \\
10.6 \mathrm{~g} \text {, total sugars } \\
10.6 \mathrm{~g} \text {, proteins } \\
0.0 \mathrm{~g} \text {, fat sat. and } \\
\text { non sat. fibers } \\
0.0 \mathrm{~g}, \text { sodium less } \\
\text { than } 10 \mathrm{mg}\end{array}$ & $\begin{array}{l}\text { Water, orange juice from } \\
\text { concentration (min 15\%) } \\
\text { sugar, citric acid, pectin, } \\
\text { sodium citrate, natural orange } \\
\text { flavor }\end{array}$ & $\begin{array}{l}\text { Carbonate water, sucrose, glucose, } \\
\text { phosphoric acid, acidifier citric acid, } \\
\text { taurine }(0.4 \%) \text {, acidity regulators } \\
\text { (sodium bicarbonate, magnesium } \\
\text { carbonate), fruit and vegetable } \\
\text { concentrates (carrot, Hibiscus), } \\
\text { flavors (natural and artificial), caffeine } \\
(0.03 \%), \text { vitamins (niacin, pantothenic } \\
\left.\text { acid, } \mathrm{B}_{6}, \mathrm{~B}_{12}\right) \text {, colours(riboflavin, } \\
\text { brilliant blue FCF) nutrition information } \\
\text { per } 100 \mathrm{~mL} \text { : energy } 193 \mathrm{KJ}(45 \mathrm{kcal}) \text {, } \\
\text { protein } 0 \mathrm{~g} \text {, carbohydrates } 10.7 \mathrm{~g} \text {, total } \\
\text { sugar } 10.7 \mathrm{~g} \text {, fat } 0 \mathrm{~g} \text {, saturated fat } 0 \mathrm{~g} \text {, } \\
\text { sodium } 0.04 \mathrm{~g} \text {, vitamins : Niacin } 8 \mathrm{mg} \text {, } \\
\text { pantothenic acid } 2 \mathrm{mg}, \mathrm{B}_{6} 2 \mathrm{mg}, \mathrm{B}_{12} \\
2 \mathrm{mg} \text {, caffeine } 32 \mathrm{mg} \text {. }\end{array}$ & $\begin{array}{l}1 \text { mg calcium } 1 \text {, magnesium } \\
20.7 \text {, sodium } 2.5 \text {, potassium } \\
9 \text {, carbonate }>1 \text {, bicarbonate } \\
12 \text {, sulphate } 77.6 \text {, } \\
\text { chlorides }<1 \text {, nitrides }<1 \text {, } \\
\text { fluoride }<0.1 \text {, total hardness } \\
<100 \text {, total dissolved solids } \\
115 \text {. }\end{array}$ \\
\hline
\end{tabular}


in the four immersion solutions are listed in Table 3. Graphs 1-4 represent mean VHN at the top, bottom surfaces of composite and compomer, before and after immersion in the four solutions respectively. t-tests comparing all the groups before and after immersion showed that there was a statistically significant difference $(p \leq 0.05)$ in all groups being tested in this study as shown in Tables 4 and 5 .

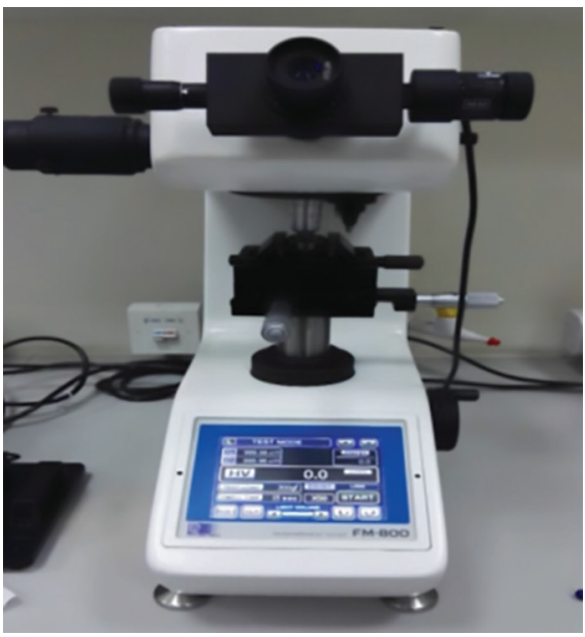

Fig. 1: Vickers microhardness tester (Microhardness tester FM-800, FUTURE-TECH, Japan) used in this study
One-way analysis of variance (ANOVA) for VHN composite top, bottom and compomer top, bottom revealed that there were statistically significant differences $(p \leq 0.05)$ as shown in Tables 6 to 9, respectively.

$\mathrm{pH}$ values for all the solutions were recorded as the followings:

- $\mathrm{pH}$ for Cola was 1.87, orange juice was 2.63, Red Bull was 2.55 and for water was 6.96 .

\section{DISCUSSION}

Restorative material in the oral cavity is being exposed to varying environmental conditions, such as acid-base reactions from drinks, which result in certain surface

Table 2: Assignment of composite and compomer groups in immersion beverage solutions

\begin{tabular}{lll}
\hline Composite & Group 1 & was incubated in Cola \\
& Group 2 & was incubated in orange juice \\
& Group 3 & was incubated in Red Bull \\
& Group 4 & was incubated in water as a control group \\
\hline Compomer & Group 5 & was incubated in Cola \\
& Group 6 & was incubated in orange juice \\
& Group 7 & was incubated in Red Bull \\
Group 8 & was incubated in water as a control group
\end{tabular}

Table 3: Mean VHN and standard deviation at the top, bottom of the eight groups being tested before and after immersion in the four immersion solutions

\begin{tabular}{|c|c|c|c|c|c|c|c|c|c|c|c|c|c|c|c|c|}
\hline \multirow{4}{*}{$\begin{array}{l}\text { Groups } \\
\text { Composite }\end{array}$} & \multicolumn{4}{|c|}{ G1 } & \multicolumn{4}{|c|}{ G2 } & \multicolumn{4}{|c|}{ G3 } & \multicolumn{4}{|c|}{ G4 } \\
\hline & \multicolumn{4}{|c|}{ Cola (Caca-cola) } & \multicolumn{4}{|c|}{ Orange juice (Rani) } & \multicolumn{4}{|c|}{ Red Bull } & \multicolumn{4}{|c|}{ Water (Arwa) } \\
\hline & \multicolumn{2}{|c|}{ Before } & \multicolumn{2}{|l|}{ After } & \multicolumn{2}{|c|}{ Before } & \multicolumn{2}{|c|}{ After } & \multicolumn{2}{|c|}{ Before } & \multicolumn{2}{|l|}{ After } & \multicolumn{2}{|c|}{ Before } & \multicolumn{2}{|l|}{ After } \\
\hline & $T$ & $B$ & $T$ & $B$ & $T$ & $B$ & $T$ & $B$ & $T$ & $B$ & $T$ & $B$ & $T$ & $B$ & $T$ & $B$ \\
\hline Mean & 52.18 & 42.38 & 40.84 & 34.14 & 54.14 & 43.19 & 39.72 & 36.14 & 53.63 & 43.9 & 41.09 & 37.53 & 54.7 & 44.37 & 47.07 & 38.99 \\
\hline SD & 5.56 & 4.59 & 3.91 & 4.53 & 2.88 & 3.29 & 1.35 & 1.31 & 2.47 & 4.9 & 2.41 & 1.82 & 1.01 & 2.77 & 1.67 & 1.67 \\
\hline \multirow[t]{3}{*}{ Groups } & \multicolumn{4}{|c|}{ G5 } & \multicolumn{4}{|c|}{ G6 } & \multicolumn{4}{|c|}{ G7 } & \multicolumn{4}{|c|}{ G8 } \\
\hline & \multicolumn{4}{|c|}{ Cola (Caca-cola) } & \multicolumn{4}{|c|}{ Orange juice (Rani) } & \multicolumn{4}{|c|}{ Red Bull } & \multicolumn{4}{|c|}{ Water (arwa) } \\
\hline & \multicolumn{2}{|c|}{ Before } & \multicolumn{2}{|c|}{ After } & \multicolumn{2}{|c|}{ Before } & \multicolumn{2}{|c|}{ After } & \multicolumn{2}{|c|}{ Before } & \multicolumn{2}{|c|}{ After } & \multicolumn{2}{|c|}{ Before } & \multicolumn{2}{|c|}{ After } \\
\hline Compomer & $T$ & $B$ & $T$ & $B$ & $T$ & $B$ & $T$ & $B$ & $T$ & $B$ & $T$ & $B$ & $T$ & $B$ & $T$ & $B$ \\
\hline Mean & 47.86 & 39.99 & 38.79 & 31.66 & 47.25 & 39.38 & 38.59 & 31.32 & 46.81 & 42.45 & 42.59 & 38 & 47.33 & 40.15 & 40.06 & 34.26 \\
\hline SD & 4,92 & 4.64 & 1.49 & 4.66 & 1.88 & 1.95 & 3.15 & 5.32 & 2.91 & 3.39 & 3.04 & 2.78 & 1.54 & 0.67 & 0.73 & 2.99 \\
\hline
\end{tabular}

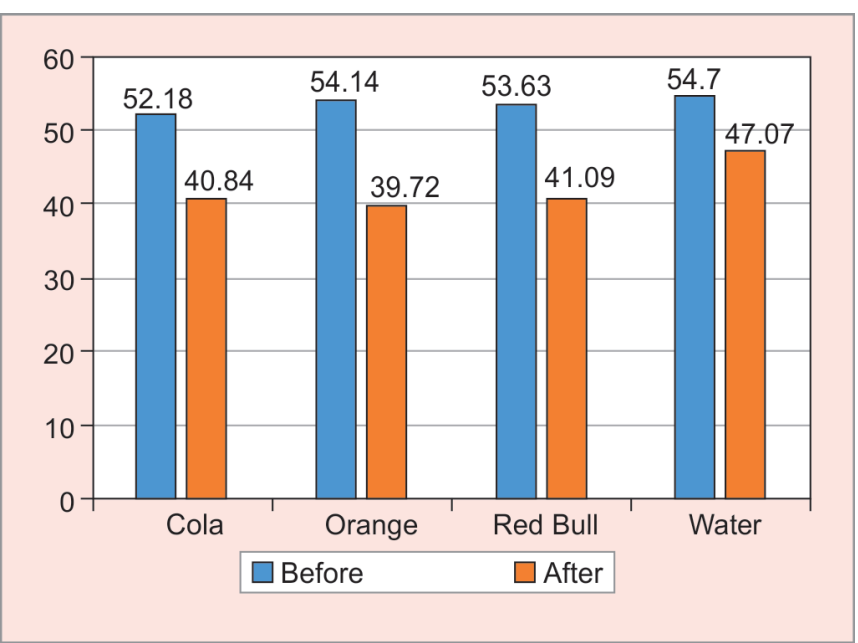

Graph 1: Mean VHN at the top composite surface, before and after immersion in the four solutions

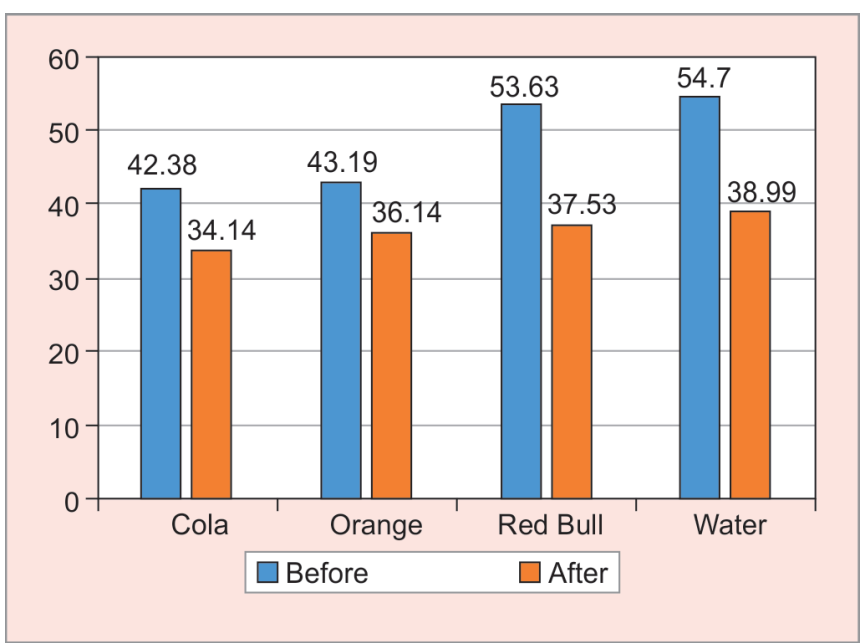

Graph 2: Mean VHN at the bottom composite surface, before and after immersion in the four solutions 


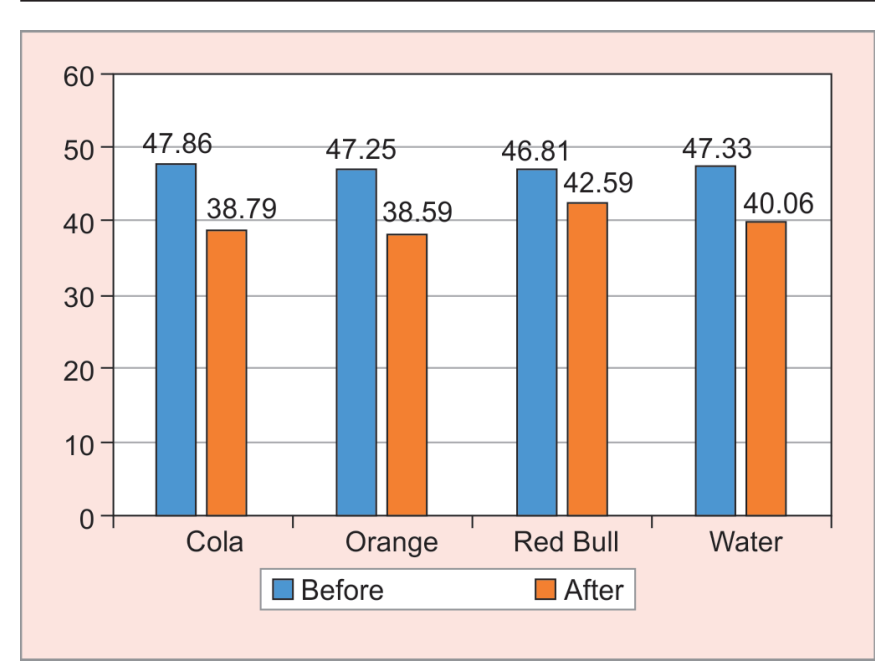

Graph 3: Mean VHN at the top compomer surface, before and after immersion in the four solutions

Table 4: t-test for composite and compomer top VHN before and after immersion in the four immersion solutions

\begin{tabular}{llll}
\hline \multirow{2}{*}{ Materials } & $\begin{array}{l}\text { Immersion } \\
\text { solution }\end{array}$ & $\begin{array}{l}p \text { value (before and } \\
\text { after immersion) }\end{array}$ & \\
\hline Composite top & Cola & $1.79092 \mathrm{E}-05$ & Sig. \\
& Orange juice & $1.2687 \mathrm{E}-07$ & Sig. \\
& Red Bull & $5.64 \mathrm{E}-06$ & Sig. \\
& Water & $1.29 \mathrm{E}-07$ & Sig. \\
\hline Compomer top & Cola & $7.52 \mathrm{E}-05$ & Sig. \\
\hline & Orange juice & $3.14 \mathrm{E}-07$ & Sig. \\
& Red Bull & $4.75 \mathrm{E}-07$ & Sig. \\
& Water & 0.000105 & Sig. \\
\hline
\end{tabular}

changes that might affect their physical or mechanical properties and eventually their long-run oral service durability. In the present study, the microhardness method was performed by immersing the restorative materials in different soft drinks (beverages) in comparison with mineral water as a control group for 30 days to detect the corresponding deteriorations from such drinks. Unfortunately, we could not find enough manufacturers data of the detailed composition of both composite and compomer materials being tested in the present study from the source since some missed details might be the main key to discuss the obtained results. Another limitation in our study was that, the study was done using one brand of composite and compomer (Promedica) which was available to us as a brand contains both products: composite and compomer together since some other brands contain only one product either composite or compomer and due to that we did not want to include the brand as another variable in the study and also because of including another brand will double the number of groups and increase the complexity and as a result double to total fees of the research, that is why we kept it as a recommendation for further studies and according to that, the results obtained from the current study, represents the PROMEDICA brand only since

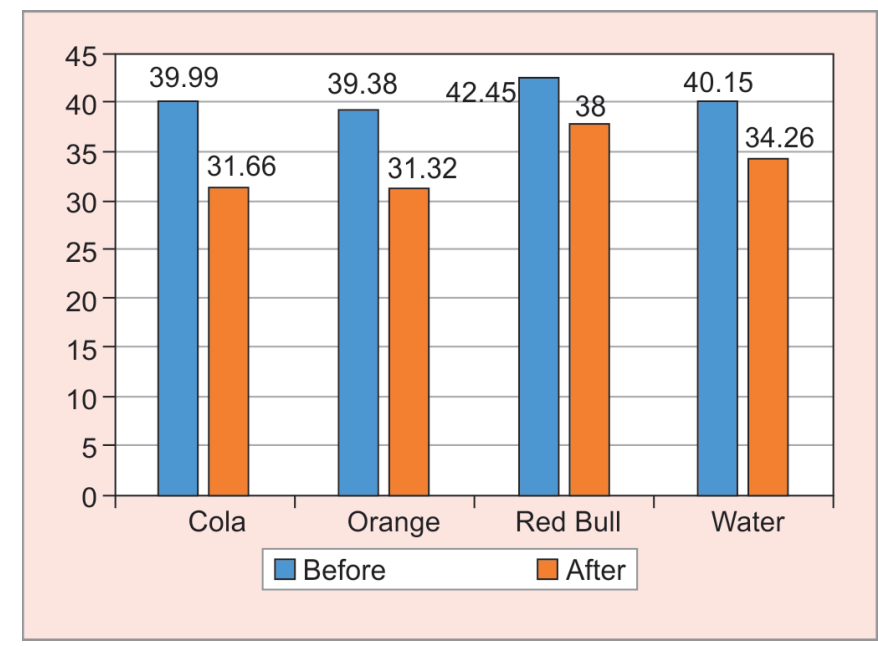

Graph 4: Mean VHN at the bottom compomer surface, before and after immersion in the four solutions

Table 5: t-test for composite and compomer bottom VHN before and after immersion in the four immersion solutions

\begin{tabular}{llll}
\hline \multirow{2}{*}{ Materials } & $\begin{array}{l}\text { Immersion } \\
\text { solution }\end{array}$ & $\begin{array}{l}p \text { value (before and } \\
\text { after immersion) }\end{array}$ & \\
\hline \multirow{3}{*}{ Composite Top } & Cola & 0.00032 & Sig. \\
& Orange juice & $3.99 \mathrm{E}-05$ & Sig. \\
& Red Bull & 0.00094154 & Sig. \\
& Water & $8.38 \mathrm{E}-06$ & Sig. \\
\hline \multirow{4}{*}{ Compomer Top } & Cola & $2.90422 \mathrm{E}-06$ & Sig. \\
\cline { 2 - 4 } & Orange juice & 0.0004647 & Sig. \\
& Red Bull & 0.000115 & Sig. \\
& Water & $7.26588 \mathrm{E}-05$ & Sig. \\
\hline
\end{tabular}

other brands might behave differently in reaction to beverages.

Further studies should include a wider range of different brands of composite and compomer or other direct restorative materials used in dentistry not being covered in our study like giomers and resin-modified GIC restorative materials. Also immersion period in our study (30-day) could be not enough to reflect real findings simulating oral conditions. Further studies should consider longer immersion periods since there are some people consume such soft drinks for years. The absence of natural saliva buffering effect might be considered as another limiting factor in our in vitro study that affects our results in reflecting real oral conditions since the minerals of natural saliva and the related buffering effect plus the effect of salivary enzymes could not be ignored as an important contributing factor affecting the results in vivo studies. The current study results indicated that immersion of restorative materials in solutions (beverages) being tested in this study, resulted in a statistically significant reduction in surface microhardness values as was shown in the statistical analysis of the results before and after immersion (Tables 4 and 5). Also, the data indicated that there was a statistically significant difference between the microhardness values 
Table 6: One-way analysis of variance (ANOVA) for VHN of composite top after immersion in the four immersion solutions

\begin{tabular}{lllllll}
\hline \multicolumn{7}{c}{ ANOVA } \\
\hline Source of variation & $S S$ & $d f$ & $M S$ & $F$ & $p$ value & F crit \\
\hline Between groups & 329.474 & 3 & 109.8247 & 17.03809 & $4.71 \mathrm{E}-07$ & 2.866266 \\
Within groups & 232.05 & 36 & 6.445833 & & & \\
\hline Total & 561.524 & 39 & & & \\
\hline
\end{tabular}

Table 7: One-way analysis of variance (ANOVA) for VHN of composite bottom after immersion in the four immersion solutions

\begin{tabular}{lllllll}
\hline \multicolumn{7}{c}{ ANOVA } \\
\hline Source of variation & SS & $d f$ & MS & $F$ & p value & F crit \\
\hline Between groups & 128.002 & 3 & 42.66733 & 6.014237 & 0.001978 & 2.866266 \\
Within groups & 255.398 & 36 & 7.094389 & - & - & - \\
\hline Total & 383.4 & 39 & - & - & - & - \\
\hline
\end{tabular}

Table 8: One-way analysis of variance (ANOVA) for VHN of compomer top after immersion in the four immersion solutions

\begin{tabular}{llllllc}
\hline \multicolumn{7}{c}{ ANOVA } \\
\hline Source of variation & SS & $d f$ & MS & $F$ & p value & F crit \\
\hline Between groups & 101.6368 & 3 & 33.8789 & 6.15635 & 0.001729 & 2.866266 \\
Within groups & 198.111 & 36 & 5.5031 & - & - & - \\
Total & 299.7478 & 39 & - & - & - & - \\
\hline
\end{tabular}

Table 9: One-way analysis of variance (ANOVA) for VHN of compomer top after immersion in the four immersion solutions

\begin{tabular}{llcclcc}
\hline \multicolumn{9}{c}{ ANOVA } \\
\hline Source of variation & SS & $d f$ & MS & $F$ & p value & F crit \\
\hline Between groups & 285.812 & 3 & 95.27067 & 5.702895 & 0.002666 & 2.866266 \\
Within groups & 601.404 & 36 & 16.70567 & - & - & - \\
Total & 887.216 & 39 & - & - & - & - \\
\hline
\end{tabular}

among the immersion solutions for the top, bottom, composite and compomer variables (Tables 6 to 9).

The present study data demonstrated that, orange juice immersion solution showed a general maximum reduction in microhardness values for composite and compomer tops and bottoms (Graphs 1,3 and 4) followed by Cola, Red Bull and Arwa ( mineral water) as a control solution except for composite bottom, cola has shown the maximum reduction in microhardness values (Graph 2). The increase in the use of resin-based restorations made them more prone to be exposed to diverse conditions of oral environment, which can result in chemical degradation $^{9}$ and reduction in physical properties, ${ }^{10}$ consequently, reduction in performance and clinical longevity of the material. The possible reason for this deterioration in physical and mechanical properties of restorative materials might be due to the differences in composition of immersion solutions, the type of particular acids incorporated in each solution, the particular $\mathrm{pH}$ and acidic concentration in that specific solution which affects significantly the surface hardness values negatively due to the degradation and erosion of matrix/ filler interface. ${ }^{11}$ Many previous studies have shown that fillers tend to fall out from resin materials ${ }^{12}$ and the matrix component decomposes when exposed to low $\mathrm{pH}$ environments. ${ }^{13,14}$ The data of this study indicated that, the orange juice resulted in microhardness reduction due to the effect of citric acid that had higher PKA value than phosphoric acid that found in Red Bull and Coca-Cola, and this finding was not in agreement with the findings reported by Sedighe ${ }^{15}$ who stated that, the result in reduction of microhardness in all specimens immersed in 100\% orange juice and non-alcoholic beer was with no significant difference which might be attributed to the differences in acidity between fully natural orange juice $(100 \%)$ used in his study and artificial orange juice (Rani) (Table 1) with low $\mathrm{pH}$ values used in the current study $(2.63 \mathrm{pH})$. Red bull showed less effect on microhardness values registered in the current study due to the incorporation of acidity regulators in spite of its low $\mathrm{pH}$ value $(2.55 \mathrm{pH})$ (sodium bicarbonate, magnesium) (Table 1).

Although the $\mathrm{pH}$ of the water immersing solution used in this study (Arwa showed in Table 1) $(6.96 \mathrm{pH})$ was very close to the mean $\mathrm{pH}$ of the oral cavity is $6.28-7.34,{ }^{16}$ but we found that the major reduction in micro-hardness values in general after immersion might be attributed to the effect 
of water content rather than the effect of solution acidity. Water sorption that resulted in swelling of composite and compomer, was considered to be the major factor in the resulted general microhardness values reduction. In the present study, although compomers displayed a significantly general lower hardness values than composite restorative materials before and after immersion (Graphs 1 to 4 ) in all the solutions being tested due to their lower volume fraction filler and the incomplete silanization of the filler ${ }^{17}$ but composites showed higher differences in microhardness values than compomers in all the immersion solution when microhardness values were being compared before and after immersion (Graphs 1 to 4 ) and this finding was not in agreement with some previous studies. ${ }^{18,19}$

\section{CONCLUSION}

Within the limits of this study, we can conclude that:

- All the beverages being tested including mineral water groups significantly resulted in general microhardness reduction

- Compomers tops and bottoms displayed a significantly general lower hardness values than composite restorative materials before and after immersion

- Composites showed higher differences in microhardness values than compomers in all the beverages when microhardness values were being compared before and after immersion

- Water sorption was the major factor affecting the microhardness rather than the acidic component of the different beverages used in the study

- Orange juice was significantly the highest beverage in microhardness reduction of both restorative materials.

\section{CLINICAL SIGNIFICANCE}

Beverages contain chemical components and their acidic nature or water content might affect the hardness of direct restorative materials that might lead to the degradation at the matrix/filler interface by acid attack and consequently a negative effect on the general performance of the affected restoration in oral service.

\section{REFERENCES}

1. Coban B, Kirzioglu Z, Altun A. Can onlay's be an alternative restoration for severely damaged primary teeth. Eur J Dent 2017;11(1):48-52.

2. Arslanoglu Z, Altana H, Sahinb O, Tekinc MG, Adigüzeld M. Evaluation of Surface Properties of Four Tooth-
Colored Restorative Materials. A Phys Pol A 128.2B 2015: B-310-B-13.

3. Nicholson J. Polyacid-modified composite resins (compomers) and their use in clinical dentistry. Dent Mater 2007;23(5):615-622.

4. Santos C, Clarke R, Braden M, Guitian F, Davy K. Water absorption characteristics of dental composites incorporating hydroxyapatite filler. Biomaterials $2002 ; 23(8): 1897-1904$.

5. Hamouda IM. Effects of various beverages on hardness, roughness, and solubility of esthetic restorative materials. J Esthet Rest Dent 2011; 23(5):315-22.

6. Anusavice KJ. Phillips' science of dental materials. 10th Ed. Philadelphia: WB Saunders, 1996:211-235.

7. Hengtrakool C, Kukiattrakoon B, Kedjarune-Leggat U. Effect of naturally acidic agents on microhardness and surface micromorphology of restorative materials. Eur J Dent 2011; 5:89-100.

8. Erdemir U, Yildiz E, Eren M, Ozel S. Surface hardness evaluation of different composite resin materials: influence of sports and energy drinks immersion after a short-term period. JAOS 2013;21(2):124-131.

9. BagheriR, Burrow MF, Tyas M. Surface characteristics of aesthetic restorative materials-An SEM study. J Oral Rehabil 2007; 34:68-76.

10. Yap AU, Tan SH, Wee SS, Lee, CW, Lim EL, Zeng KY. Chemical degradation of composite restoratives. J. Oral Rehabil. 2001 28; 1015-1021.

11. Yap AU, Low JS, Ong LF. Effect of food-simulating liquids on surface characteristics of composite and polyacid-modified composite restoratives. Oper Dent 2000; 25:170-176.

12. Neamat AB, Han L., Okamoto A, Iwaku M. Effect of alcoholic and low $\mathrm{pH}$ soft drinks on fluoride release from compomer. J Esthet Dent 2000; 12: 97-104.

13. Bayne SC, Thompson J, Swift Jr, Stamatiades P, Wilkerson M. A characterization of first generation flowable composites. J Am Dent Assoc 1998; 129: 567-577.

14. Kitchens M, Owens BM. Effect of carbonated beverages, coffee, sports and high energy drinks, and bottled water on the in vitro erosion characteristics of dental enamel. J Clin Pediatr Dent 2007; 31: 153-159.

15. Sadat S, Kamangar H, Ghavam M, Mirkhezri Z, JavadKarazifard M. Comparison of the Effects of Two Different Drinks on Microhardness of a Silorane-based Composite Resin. J dent 2015; 16(3): 260-266.

16. Aframian DJ, Davidowitz T, Benoliel R. The distribution of oral mucosal $\mathrm{pH}$ values in healthy saliva secretors. Oral Dis. 2006; 12:420-423.

17. Ruse ND. What is a compomer? J Can Dent Assoc, 1999; 65:500-504.

18. Geurtsen W, Leyhausen G, Garcia-Godoy F. Effect of storage media on the fluoride release and surface microhardness of four polyacid-modified composite resins ("compomers") Dent Mater 1999; 15:196-201.

19. Attin T, Buchalla W, Trett A, Hellwig E. Toothbrushing abrasion of polyacid-modified composites in neutral and acidic buffer solutions. J Prosthet Dent 1998; 80:148-150. 